\title{
Erratum to: International Establishment Mode Choice: Past, Present and Future
}

\author{
Desislava Dikova' ${ }^{1}$ Keith Brouthers ${ }^{2}$
}

\section{Erratum to: Manag Int Rev \\ DOI 10.1007/s11575-015-0258-3}

The original version of this article unfortunately contained a mistake. The presentation of Table 5 was incorrect. The original article was corrected.

The publisher apologises for this mistake.

The online version of the original article can be found under doi:10.1007/s11575-015-0258-3.

Desislava Dikova

desislava.dikova@wu.ac.at

1 Department of Global Business and Trade, Vienna University of Economics and Business, Vienna, Austria

2 King's College, London, UK 